\title{
Policy paradigms and path dependence: the endogenous roots of institutional displacement and drift in India
}

\author{
Rahul Mukherji ${ }^{1}$. Seyed Hossein Zarhani ${ }^{1}$
}

Received: 20 January 2021 / Accepted: 30 January 2021 / Published online: 19 February 2021

(C) The Author(s), under exclusive licence to Institute for Global Public Policy, Fudan University 2021

\begin{abstract}
This paper demonstrates the impact of path-dependent policy paradigms on institutional progression. This could involve institutional journeys from democracy to authoritarianism, from federalism to centralization, and vice versa. First, we posit that policy ideas are more important than material interests for the evolution of historical paths. Second, the sequence of path construction is equally important. This paper points to the significance of policy ideas for the construction of two sequences - a layering-tipping-displacement path-and a path of institutional drift. Our case work describes how the layered evolution of ideas led to a tipping point that transformed a public sector-driven regime into a private sector oriented one in 1991, thereby unleashing India's rapid economic growth. The causal mechanism suggests that layering leading to a tipping point that displaces the old paradigm can reveal why overtly abrupt change may result from gradual endogenous processes. This is a largely unexplored causal mechanism in comparative politics. The paper also demonstrates that an ideational drift away from the federalising frame evolved since 2014. It has resulted in famishing the Indian sub-national states for development expenditure, especially at the time of COVID-19. Scholars have suggested the causal logic behind conversion, drift, layering and displacement largely based on material factors. This paper connects ideas embedded in policy paradigms with two of these paths.
\end{abstract}

Keywords Historical institutionalism - Path dependence · Policy paradigms · Governance $\cdot$ Political economy $\cdot$ India

JEL Classification B52 $\cdot$ D73 $\cdot$ D83 $\cdot$ P16

Communicated by Yijia Jing.

Rahul Mukherji

mukherji@uni-heidelberg.de

1 Department of Political Science, South Asia Institute, Heidelberg University, Voßstr. 2, Building 4130, 69115 Heidelberg, Germany 


\section{Introduction}

The paper demonstrates that historical institutionalism needs to take ideas embedded in policy paradigms seriously to explain how conflicts of interest shape historical paths. Every institution has a moral basis that impacts behaviour. If, for example, the import substitution (IS) or the closed economy model is the dominant policy paradigm, the state is likely to be far more in control of private corporations, than if growth was to be based on entrepreneurial freedoms to make the best investment decisions. This paper conceptually and empirically explores the relationship between policy paradigms and two different historical paths. First, the paper proposes a policy paradigms and layering-tipping-displacement model (PPLTDM). This model suggests that gradual layered change - that is gradual change in policies and legislations that form a new layer of a new institution on top of an old established one can tip after reaching a threshold. ${ }^{1}$ The tipping mechanism, which appears like a sudden institutional displacement is really the result of long drawn endogenous processes. This model is deployed to explain the economic reforms of July 1991 that form the basis of India's rapid economic growth.

Second, we also posit that policy ideas or paradigms can drift in a different policy direction as well. Drift is a historical sequence or path where policy makers seek to nudge institutions in a different direction just by interpreting rules differently (Hacker et al. 2015). We explain the evolving mechanism of financial devolution to the Indian sub-national states as drift towards the centralization of financial allocations. No new laws challenge the federal structure of resource allocations. In fact, the Goods and Services Tax (GST) Act (2017), which centralized tax collections came with a federally negotiated revenue sharing arrangement between the Centre and the sub-national states. The Indian state has not fulfilled that promise (Mukherji 2020). To make matters worse, not only is the Centre not compensating the subnational states for the decline in revenues, rather it is encouraging them to borrow at market rates under conditions prescribed by it.

These above-mentioned argument regarding our first model (PPLTDM) challenge four popular explanations of India's economic reforms. The first is the class-based logic that would suggest that India's economic reforms were driven by the interests of the industrial class (Pedersen 2000). Our understanding of the Indian business class rejects this view for two reasons. We agree with economists such as Jagdish Bhagwati, Padma Desai, T N Srinivasan and Pranab Bardhan who have argued convincingly that India's industrialization had become a rent-seeking racket that was favoured by India's powerful industrialists. ${ }^{2}$ The state afforded protection in return for the rents it earned from powerful business groups. Such was the power of these groups that Prime Minister Rajiv Gandhi (1984-1989) gave prominence to the relatively insignificant Association of Indian Engineering Industry to direct attention to

\footnotetext{
${ }^{1}$ For layering, see Streeck and Thelen (2005), Tsai (2006), Mukherji (2009) and Mahoney and Thelen (2010). On the tipping point, see Mukherji (2013, 2014).

${ }^{2}$ Fort the literature on why IS became a rent-seeking racket, see Jagdish Bhagwati and Desai (1970), Jagdish Bhagwati and Srinivasan (1975) and Bardhan (1984).
} 
manufacturing industry rather than the privileged trading class represented in the Federation of Indian Chambers of Commerce and Industry (FICCI). The FICCI had even opposed the big bang industrial deregulation of 1991 that substantially reduced internal and external controls. ${ }^{3}$ We note that India's famous information technology (IT) revolution was not due to any pressure from entrepreneurs. Rather, it was the result of the way in which the Department of Electronics (DOE) directly under the Prime Minister's Office (PMO) worked with qualified engineers who later became the iconic first generation IT entrepreneurs (Pingle 1999).

A second group of explanations suggests that India's reforms were an elite revolt driven by the interests of the Indian middle class. There is a view that the middle classes desired deregulation to achieve developed country standards of living. This persuaded a group of elites to promote both deregulation and globalization-with the hope that this would bring those very benefits (Patnaik and Chandrasekhar 2007; Kohli 2006). While this idea has been powerfully expressed, it is well known that public sector employment as a proportion of total employment continued to remain significant decades after the reforms were introduced (Sridharan 2008). Moreover, a reading of the newspapers and scholarly material around 1991 suggests that the proponents of closure were more powerful in the press and in the academia. ${ }^{4}$

Finally, were the reforms of 1991 driven by pressure from the International Monetary Fund (IMF) at the time of a balance of payments crisis? After all, the reforms and the crisis both coincided. This would support the critical juncture argument, where a short-term external impact creates a new punctuated equilibrium with longterm consequences (Capoccia and Kelemen 2007; Capoccia 2016; Krasner 1984). We, on the other hand, argue that this was not the case. It was the dominant ideas within the state that propelled the economic reforms of 1991. There is a history that suggests that India does not easily bow to foreign pressure. It posed a challenge for the critical juncture argument. India faced a similar balance of payments crisis in 1966, when it did not have enough finances to buy necessary food-grains from the US at the time of an impending famine. Even then, when the idea of IS was hegemonic in India, the country only briefly made minimal adjustments to secure food-grains from the US (Denoon 1986; Mukherji 2014). In fact, the phase from 1967 till 1974 constitutes the period of most stringent industrial controls in India's post-colonial history. The preferences held within the state could not be trumped by foreign pressure even during a vulnerable moment. The same can be said about India's seeking the IMF in 1980. This time, India used the IMF's need to draw India into its activities after the second oil shock to build public sector assets with IMF funds. Not only was there no IMF driven deregulation, India quickly came out of the

\footnotetext{
3 This view is based on a number of sources: personal interview with D H Pai Panandiker, Secretary General of FICCI (2 June 2009). Also see Mukherji (2014); Kantha and Ray (2006); Sinha (2005) and Kochanek (2007).

4 This view is based on Mukherji's reading of newspapers of that period.
} 
stabilization package with excellent public sector assets (Ruggie 1983; Chaudhry et al. 2004). ${ }^{5}$

We hold that India followed the largely gradual and endogenous PPLTDM path when India's IS institutions were displaced by institutions favouring deregulation and competitiveness in 1991. The state was adding layer after layer of the private sector promotion policies and instruments driven by the deregulation paradigm since the late 1970s. India's IS institutions tipped in favour of deregulation in $1991 .^{6}$ The balance of payments crisis became an instrument in the hands of a convinced technocratic elite within the state to push for big bang industrial deregulation. It is these endogenous processes that made the system tip, rather than the exogenous shock of the Gulf War (October 1990) that precipitated a balance of payments crisis. Most economists would argue that a relatively minor exogenous shock driven largely by India's poor fiscal management led to the crisis, because India's fiscal situation had deteriorated considerably (Joshi and Little 1994; Mukherji 2007). The shock was like the last bicycle that went over a bridge that collapsed as result of its own infirmities. India had earlier weathered more powerful exogenous shocks with greater ease in 1973 and in 1980.

India's tryst with the IMF was successful, because the Indian state successfully resisted the IMF's orthodox prescriptions. The IMF respected the Indian technocrats because of the significant evolution of policy thinking and practice in India. The country successfully deviated from the classic Washington Consensus of bringing down the unions, severely cutting the budget deficit, privatizing public sector assets and radically reducing subsidies. The success of India's heterodox approach is an outlier in the saga of IMF's substantial failures. ${ }^{7}$ It is for these reasons that one of the key architects of the Indian reforms, Montek Singh Ahluwalia was appointed the first Director of the Independent Evaluation Office of the IMF (Ahluwalia 2020).

Finally, it has been argued that the reforms of the 1980s were carried out by stealth (Jenkins 1999). This argument is closer to the logic of drift that would suggest that policy makers gradually kept interpreting the laws differently because of the ambiguities inherent in them. This is similar to Israel's turn towards private sector job settlements for immigrants (Koreh et al. 2019). This paper also deploys the logic of drift to explain the case of India's move towards centralizing financial allocations to the sub-national states.

The paper, however, holds a different view regarding India's deregulation path. While some policies such as the de-control of cement could be characterised as stealth or drift (Ahluwalia 2020), the vast gamut of industrial de-control occurred

\footnotetext{
${ }^{5}$ See also Ahluwalia $(2020,58-60)$. Ahluwalia reports in his memoirs that he was personally present in these meetings.

${ }^{6}$ These experiments and their positive economic impact have been described by a number of authors even though they have not been conceptualized as layering. See Rodrik and Subramanian (2004), Kohli (2006), (Ganguly and Mukherji 2011).

${ }^{7}$ On the nature of interactions between the IMF and the Indian government, see Mukherji (2014, 86-89). This reference is based on a reading of primary materials and discussions with technocrats who dealt with the IMF. On the largely negative impact of the IMF on countries in need of finance, see Boughton (2003), Vreeland (2003) and Stone (2008).
} 
through the more explicit process of layering. ${ }^{8}$ We hold that powerful veto players did not allow radical changes in favour of deregulation in the 1980s. However, the rules of the game were so unambiguously opposed to private sector freedoms that drift would not work. The state generally opted for an explicit layered approach to formal private sector deregulation following the PPLTDM model. We conceptualize that process in the next section and explain the case of 1991 in the subsequent section.

In the second section, we integrate ideas with paths and discuss the two abovementioned causal mechanisms. The third section presents the empirical materials of the theoretical argument. Integrating policy paradigms with slow moving phenomena such as drift and layering can tell us why we are surprised by phenomena such as democratic backsliding and the rise of leaders like Trump and Modi. It can also reveal why ethnic majoritarianism, that seemed so unlikely in the modern world is threatening democracies in all continents.

\section{Endogenous causal mechanisms and pathways}

This section will connect ideas with two path-dependent causal mechanisms involving policy paradigms. This first is the policy paradigm and layered-tipping-displacement model (PPLTDM). It is driven by institutional layering that ultimately displaces the old regulatory regime with a tipping mechanism. The second is a model of institutional drift based on economic ideas. ${ }^{9}$

Historical institutionalism (HI) does note that critical junctures impacted by short-term exogenous shocks come with long-term consequences. If for example, a meteor led to the extinction of dinosaurs, this would have permitted the evolution of many animals that could not thrive in a society of dinosaurs. To give two examples of critical junctures: imperial control or IMF pressure at the time of a balance of payments crisis can be construed as external shocks that carry the potential of transforming institutions. ${ }^{10}$ Exogenous shocks are a handy tool for explaining why institutions change.

This paper takes the opposite view. It stresses gradual endogenous change (Pierson 2004). We discuss two paths concerned with gradual endogenous change. The first path is a layered one that tips in favour of institutional displacement. An institution is displaced when one set of norms is replaced by another set of norms. To give an example, the Glorious Revolution of 1688 and the rise of the Bank of England and the British Parliament led to substantial rise in the power of capital in relation to the monarchy (North and Weingast 1989). Scholars hold that institutional

\footnotetext{
8 Ahluwalia was a player in this policy. His memoirs are like primary material. His characterisation of the difference between stealth and gradualism is similar to the difference between drift and layering.

9 On the challenges to institutional change, see David (1985); Mahoney (2010); Mukherji (2014) and Hacker et al. (2015).

10 On critical junctures that can transform domestic institutions, see Capoccia (2016); Capoccia and Kelemen (2007), Hirschman (1989) and Robinson and Acemoglu (2012).
} 
displacement can occur with weak veto players when insurrectionary change agents bring about clear legal changes (Mahoney and Thelen 2010). Displacement with strong veto players and more opportunistic agents in India poses a puzzle. This was precisely the case when India embarked on its far-reaching reforms in 1991. How can one reconcile strong veto players and opportunistic change agents with a sudden and radical transformation in 1991? We turn to PPLTDM to answer this question in the next section.

\section{Policy paradigms and layered-tipping-displacement model (PPLTDM)}

We propose that a layered tipping model can also produce institutional displacement. Often what looks sudden can be the result of long-term endogenous processes. Layering is one such long-term endogenous process of institutional change. Layering involves allowing a new rule to sit on top of an old rule and allowing it to grow differentially in relation to the old rule. If, for example, the dominant view of the state is stringent controls over the private sector to direct economic self-sufficiency, a layered approach would require that a law or policy or rule promoting entrepreneurship is made to sit on top of the old paradigm of stringent controls (Mukherji 2009; Mahoney and Thelen 2010). As layers of such explicit rules advance, the older paradigm becomes weaker.

Institutional layering is facilitated by two environmental conditions. First, it generally occurs when the veto players opposed to the layered evolution of laws and policies favouring a new institution are powerful. This ensures that no radical legal or policy changes are possible. Second, it occurs when the rules have to be unambiguously changed to redirect the institutional trajectory. Layering would not be required if the rules were so ambiguous that they could be interpreted differently for different purposes.

Layered processes can be driven as much by material interests as they may be driven by ideationally driven policy paradigms. If, for example, we were to argue that the privatization of risk in US healthcare and retirement planning was driven by the power of the corporate sector, this would be a materially based explanation. ${ }^{11}$ If, on the other hand, we argue that these changes were driven by an economic policy paradigm that became powerful within the state, then we are in the realm of policy paradigms or ideas as movers of the layered process. Mark Blyth (2002), for example, has argued why Keynesianism became a powerful policy idea that led to state intervention in the economy through the New Deal in the US. ${ }^{12}$ Similarly, overregulation or government failure became a powerful economic idea that earned many powerful adherents. ${ }^{13}$ We hold that the Indian transformation towards deregulation

\footnotetext{
11 Good examples of the power of capital is found in North and Weingast (1989) and Streeck (2014).

12 Blyth et al. (2016) also pointed out that while scholars who stress ideas have used historical institutionalism, many of the leading historical institutionalists have ignored the scholarship on ideas.

13 See for example Stigler (1971) and Posner (1974). For a good account of how these ideas got embedded within the US state, see Derthick and Quirk (1985). For the most powerful accounts of why overregulation was a problem in the developing world, popularised through the concept of rent-seeking indus-
} 
was a layered process driven by the idea that overregulation was detrimental for growth and competitiveness.

Ideationally layered processes can tip. A tipping point is a good way to understand why long-drawn endogenous processes can suddenly appear as abrupt change. Water suddenly begins to boil at 100 degrees centigrade but only after heat has been consistently supplied over a period of time. Earthquakes too appear sudden, but they are the result of long-drawn tectonic shifts under the earth's surface. Science can predict the temperature at which water begins to boil. Meteorologists may have known that an earthquake is imminent even though they could not precisely predict a Fukushima. In our case, like in most social science, a priori predictions are impossible. However, like meteorologists, if we look carefully at historical data, social tectonic movements can be discerned. If the system has moved substantially in the direction of deregulation, in a layered manner, we can say that a system has tipped towards institutional displacement largely for endogenous reasons. ${ }^{14}$

Such an ideational tipping point driven by a layered process is a good way to understand institutional displacement. Even though this mechanism has not been properly conceptualized, there is substantial evidence pointing in that direction. Peter Hall's (1993) work on the rise of neoliberalism in Britain suggests that firstand second-order changes were the result of technical thinking within the Treasury and the Bank of England. The narrative does not easily clarify whether third-order change or paradigm change constituted a tipping point or a critical juncture. ${ }^{15}$ Jha (2020) has argued that the norm of secrecy, which was largely challenged by opposition parties from 1947 till 1990, became a part of ruling party politics after 1991. The system tipped around 2005, when the Right to Information was enacted. In a similar vein, it has been argued that the Communist Party of India (Marxist) reputed for redistributive policies, proceeded in a layered way in the direction of a market driven paradigm and could not even implement the right to work with substantial effect. This redistributive failure had much to do with the triumph of trickle-down economics in West Bengal around 2005 (Mukherji et al. 2019).

These narratives suggest that the PPLTDM requires greater conceptual and empirical validation. We will argue in the next section that deregulation in India was driven by considerable thinking within the Indian technocracy that found political support, despite powerful veto players opposed to it. This is consistent with the literature on the bureaucracy that argues that new ideas within the bureaucracy can make a political impact (Hall 1993; Menahem 2008; Mukherji 2014; Carstensen and Matthijs 2018). Such an explanation should clarify how the policy objectives and instruments changed so that they were revealed in the new set of policies or legislations (Daigneault 2014). This layered evolution over the 1980s led to a tipping point

\footnotetext{
Footnote 13 (continued)

trialization, see Jagdish Bhagwati and Srinivasan (1980); Krueger (1974); Jagdish Bhagwati and Desai (1970) and Bhagwati and Srinivasan (1975).

14 For details on the tipping model, see Mukherji (2014).

15 On whether third order change in policy paradigms is rational, see Blyth (2013); Mukherji (2014).
} 
in 1991, when the goals of policy were changed fundamentally for largely endogenous reasons.

\section{Policy paradigm and the drift model (PPDM)}

The second path is captured in the policy paradigm and drift model (PPDM). This institutional environment has strong veto players that render legal change difficult. However, ambiguity in the rules can be interpreted in a way that allows the old institution to evolve in a different way. Small changes in institutional interpretation are possible without substantially changing the rules. Institutional drift can both be the beginning or the continuation of a long-drawn process of institutional change.

There are several conditions that can facilitate drift. First, a change in background conditions such as technological change can engender drift. For example, the IT revolution facilitated financial deregulation simply because the IT revolution posed new challenges for regulation. The old rules would not be able to deal with technological change to bypass the rules (Hacker et al. 2015; Mahoney and Thelen 2010; Béland 2007; Hacker 2004).

This paper takes the view that drift can also be driven by ideas such as deregulation. In Israel's conservative milieu, unions were rendered less powerful by the conservative Likud government and the Ministry of Finance in the late 1970s. The drift towards privatized job placement in Israel occurred despite the Employment Security Act (1958), which was pursuing the goal of full employment with immigrants. The Ministry of Labor Welfare did not receive any additional budget despite the boom in immigrants between 1980 and 1985 (Koreh et al. 2019). Similarly, Hacker (2004) tells a story regarding how the idea of giving private health companies preference allowed the American healthcare system to drift towards greater emphasis on private companies. In both the cases, the advance of the neoliberal policy paradigm of providing greater freedoms to private enterprises was behind the drift in policies.

In the next section, we find that India's drift towards financial centralization was driven powerfully by the dominant centralizing paradigm within the executive arm. Given the sovereign status of sub-national states with veto powers in India, there would be powerful veto against a legislative option (Rudolph and Rudolph 2007; Zarhani 2019). Case 2 in the next section will describe the Centre's failure to fulfil its fiscal promise to the sub-national states, despite no overt change in laws and policies. This constitutes a drift towards centralization of financial control.

\section{Cases}

\section{Case 1: the reforms of 1991: policy paradigms and layered-tipping-displacement model (PPLTDM)}

The reforms of 1991 largely followed the policy paradigms and layered-tippingdisplacement model (PPLTDM) described above. The period from 1979 till about 1984 was a time when the Government of India (GOI) pointed to the problems with 
India's IS closed economy model. The IS paradigm was based on excessive regulation of industry, inefficient deployment of public sector assets, and the need to promote self-sufficiency. The layered deregulation largely occurred in the subsequent period from 1985 till 1990. During the first phase till 1985, adjustments were made mostly in policy settings such as deregulating industrial controls (or licensing). In the second phase, some new instruments were created largely in the area of taxation, telecommunications and IT. This progression continued despite changes in ruling parties with varied professed ideological orientations. Ideas within the state moved gradually in a layered way towards competitiveness and deregulation, when the dominant paradigm was IS with stringent industrial controls.

The GOI discretely criticized the dominant IS model from the late 1970s till the mid-1980s. A committee chaired by Vadilal Dagli (1979) criticised industrial controls. ${ }^{16}$ Two influential reports on trade reforms stressed the importance of import liberalization and efficient IS for export promotion (Alexander 1978; Hussain 1984). The Dagli recommendations influenced the Industrial Policy Statement of 1980. The production capacity of a firm in excess of the government licence was to be regularized. Some ease in increasing production capacity was also permitted in an era of stringent production controls. These decisions helped industrial conglomerates like Reliance to grow rapidly in the 1980s (Ahluwalia 2020, 49-50).

Two of the architects of India's IS — Lakshmi Kant Jha and Indraprasad Gordhanbhai Patel-became frank critics of the system of controls in the 1980s (Patel 1987, 2003; Mukherji 2014). In 1981, the Harish Chandra Sarin committee on telecommunications recommended that the Ministry of Communications be separated into two departments - the Department of Telecommunications and the Department of Posts. This historic recommendation was recognition that telecommunications was to assume a greater role in India's communications and growth (Mukherji 2009).

Influential committees criticised the inefficiencies in India's IS model. A committee chaired by Arjun Sengupta pointed out the reasons behind the poor performance of public investment (1984). The phenomenal growth of public investment was largely unprofitable due to political interference. Publicly owned companies were encouraged to approach the financial market, especially in sectors where private companies had participated. Lakshmi Kant Jha chaired an influential committee on administrative reforms (1986). Jha had expressed the view that the Indian economy was moving with so many breaks (industrial controls) that just releasing a few would lead to a growth surge. ${ }^{17}$ Maidavolu Narasimham chaired another committee that recommended financial deregulation (Narasimhan 1985).

The above-mentioned reports recommended changes in policy settings to deregulate investment. The most successful foreign investor Suzuki was given an allowance to manufacture 100,000 cars when its Indian competitors were allowed just 20,000 (Ahluwalia 2020, 50-53). The Maruti-Suzuki car quickly displaced the hegemony of the Ambassador and the Fiat. Industrial controls were especially relaxed in sectors

\footnotetext{
16 Janata Party was the first non-Congress government in the history of independent India (1977-1980).

17 This view is based on personal interview with a reform architect Montek Singh Ahluwalia in May 2010. See also Ahluwalia $(2020,78)$.
} 
such as IT, pharmaceuticals and automobile parts- the three success stories of India's subsequent globalization. Prime Minister Rajiv Gandhi (1984-1989) raised the investment limits of the Monopolies and Restrictive Trade Practices (MRTP) Act from $\$ 4.3$ million to $\$ 21.5$ million. This was perhaps the most significant relaxation of industrial controls. Deregulation continued during the premiership of Vishwanath Pratap Singh as well (1989-1990). ${ }^{18}$

There were also discernible changes in policy instruments. The value added tax was announced in the budget of 1985 and introduced in 1986. Central excise duties would be replaced with the value added tax principle of giving credit for taxes already paid for inputs. This principal was accepted by all the sub-national states in 2006, and, in 2017, GST was enacted for the entire country. The 1985 budget was widely criticized (Rubin 1985; Ahluwalia 2020).

New policy instruments were created for the subsequent boom of the telecommunications sector. Established in 1984, the Centre for the Development of Telematics (CDOT) attracted the best talent to innovate a telecom switch that was superior to the one manufactured by the publicly owned Indian Telephone Industries in collaboration with the French multinational-Alcatel. This switch licensed to private companies for production was the first entry of private companies in telecommunications. Following the Sarin Committee recommendations (1981), the Ministry of Communications was divided into two departments-the Department of Telecommunications and the Department of Posts (1985), with substantial emphasis given to telecommunications. Finally, the Mahanagar Telephone Nigam Limited (MTNL) was set up as a corporatized public sector telecom service provider relatively free from political interference in 1986. The Prime Minister's Office (PMO) wanted MTNL operations in six cities. But the political opposition was so substantial that the state succeeded with operations in just two metropolitan cities-Delhi and Mumbai. The commercial success of MTNL attracted vehement political opposition from the Department of Telecommunications (Desai 2003; Athreya 1996; Mukherji 2009).

Like telecommunications, IT the symbol of India's globalization received special attention. The IT Policy of 1984 signalled the victory of the export-oriented IT software sector over the benefits received by the IS focused hardware manufacturers. Not only were production restrictions on hardware manufacturers reduced, but the import duty on imported computers was also brought down. Hereafter, software manufacturers rather than the Department of Electronics (DOE) could decide their computer imports. The next policy document (1986) further reduced duties on hardware imports and created a more efficient "single window clearance" for entrepreneurs involved with software exports. To deal with the connectivity bottleneck, the state provided IT connectivity, office space, and tax benefits in return for exports in the software technology parks cleared by the DOE in 1990. These software

\footnotetext{
18 For the best literature for this period, see Panagariya (2008, 78-109); Ganguly and Mukherji (2011, 73-77); Sharma (2009, 124-173); Pingle (1999, 126-41); Saxenian (2007, 361-369).
} 
technology parks enabled Indian companies to compete with multinationals such as Texas Instruments. ${ }^{19}$

These changes in setting and instruments occurred in a layered manner because of strong veto players. They paved the way for gradual but discernible industrial deregulation. There was substantial political resistance. The MTNL was resisted by the DOT. The CDOT was equally resisted despite its innovative potential. The IS-oriented computer hardware manufacturers resisted the technically qualified first generation entrepreneurs who subsequently became renowned for software exports.

Despite strong veto players, Indian industry was substantially deregulated, because IS was losing its persuasive power within the state. An economy that grew at 3.4\% between 1956 and 1974, accelerated to 6.2\% between 1975 and 90 (Nayar 2006; Rodrik and Subramanian 2005). Based on a serious internal critique of the IS model, the state incorporated layered changes in settings such as investment, import deregulation and tax reduction. It also initiated new instruments such as the value added tax, the DOT, the CDOT, the MTNL, the "single window clearance" facility and the software technology parks.

The Industrial Policy Resolution and the budget of July 24, 1991, was a tipping point that led to the institutional displacement of IS premised on industrial controls with industrial deregulation and competitiveness. The state used the balance of payments crisis to negotiate a heterodox deal with the IMF that would transform the policy paradigm. Very close to the crisis, an influential technocrat in the PMOMontek Singh Ahluwalia had circulated a document on the future course of the economy based on a suggestion by Prime Minister Vishwanath Pratap Singh. This (in)famous 32 page " $M$ document" became the basis of India's reforms (Ahluwalia 2020, 109-115). This was very different from the situation in 1966 when the Indian state resisted foreign pressure to deregulate, despite a severe foreign exchange crisis.

The tipping mechanism is premised on substantial gradual endogenous movements from the original institutional position towards a new one. A small change can make a system tip and displace it after it has reached a threshold. When a system tips, for example, when water suddenly begins to boil, the state changes from liquid to vapour just after 1 degree centigrade change in temperature. A layered tipping point analogy suggests that one institution could be displaced by another in the social realm even with a minor further movement-reflecting drastic change at the tipping point.

This occurred on July 24, 1991 (Ahluwalia 2020, 142-147). Industrial licensing was largely abolished. Tariffs were substantially reduced. The currency was devalued to a realistic level. And, foreign investment was welcomed. Taken together these changes constituted a paradigm shift in economic policy from IS to deregulation for promoting industrial competitiveness (Panagariya 2008, 103-109). In the budget speech of July 24, 1991, Finance Minister Manmohan Singh proclaimed quoting Victor Hugo (Ahluwalia 2020, 145):

19 On the rise of India's software sector see Pingle (1999); Saxenian (2007) and K. Sridharan (1996). 


\section{Case 2: Policy paradigm and the drift model (PPDM): centre-state financial relations}

This section discusses the impact of the National Democratic Alliance (NDA) government's approach to GST implementation during the COVID 19 pandemic on centre-state financial relations. ${ }^{20}$ This case constitutes a drift towards centralization in India's federal structure following the PPDM. Drift connotes a situation where ambiguous rules are interpreted differently in the presence of powerful veto players, to nudge an institution in a different direction. The PPDM described above does not require a substantial path dependent history, because normative drift may be in its early stages. Apart from centre-state financial relations in India, centralization of authority is also evident in other arenas such as the farm produce legislations (2020), and abrogation of Article 370 (2019) — which reduced Jammu and Kashmir from a special status sub-national state to a union territory with fewer autonomous powers than the sub-national states. ${ }^{21}$ We clarify how in the presence of strong veto players, the COVID-19 crisis was deployed to centralize federally negotiated revenue allocation decisions.

In this section, first, we describe the current trends in sub-national state finances favouring centralization. Second, we provide a brief historical overview of the evolution and reforms in fiscal relations between the Centre and the sub-national states. Finally, we demonstrate how the central government has deployed GST implementation during the pandemic to violate the sovereign rights of the sub-national states. The new interpretation of rules and conventions constitutes a drift towards fiscal unionism.

In the last 6 years, the sub-state governments' debt as a ratio of their gross state domestic product (GSDP) has grown sharply in comparison to the Centre. Since 2014, this ratio has increased by $4.3 \%$ from $22.3 \%$ of the Gross State Domestic Product (GSDP) in 2014 to $26.6 \%$ as per the budget estimates of 2020-21 (see Fig. 1). ${ }^{22}$ This trend contrasts with the previous trend when the state governments 'debt fell by around $10 \%$ from a peak of $31.8 \%$ in 2004 to $22.2 \%$ in 2013 . The new findings of Crisil research project an even gloomier picture (Shetty 2020).

Moreover, while the central government whose debt to GDP ratio fell from $52.2 \%$ (2013/2014) to 50.7\% (2020/21) (Reserve Bank of India, 2020a, 305), the mounting debt of the sub-national state governments is disquieting. Is this because the Centre is unwilling to assume certain fiscal responsibilities at the sub-national level? ${ }^{23}$

\footnotetext{
${ }^{20}$ The NDA is the right of centre National Democratic Alliance headed by the Bharatiya Janata Party (BJP) heading the government from 2014 to 2021. UPA, on the other hand, is the left of centre United Progressive Alliance coalition, which ruled from 2004 to 2014.

21 For the farm bills, see Singh (2020).

22 For more details see Reserve Bank of India (2020a, 31).

23 The government's former economic advisor Arvind Subramanian (2019) has argued that India's growth between $2011 / 12$ and $2016 / 17$ has been about $4.5 \%$ rather than $7 \%$.
} 
Despite constitutional provisions safeguarding the states, centre-state financial relations in India began with a centralizing impulse after $1950 .{ }^{24}$ There were three important reasons for this. First, the Centre had substantial revenue collection and allocation powers; thereby making the states dependent on the Centre. Second, the pre-independence rules of borrowing from the Centre that had been adopted in the Constitution (see article 292 and 293 of the Constitution) also did not help. Third, the Nehruvian model of centrally planned economy and its organizational manifestation-the Planning Commission-had empowered the Centre extensively in planning and allocation. The states became habituated to live with excessive borrowings from the Centre leading to alarming levels of the debt to GSDP ratio around 2003 (31.8\% in Fig. 1). This problem was subsequently addressed by increasing the revenue generating powers of the sub-national states and reducing their dependence on Central borrowings (Garg 2021, forthcoming).

The federalism saga was consolidated by the economic reforms of 1991 (Saez 2002; Rudolph and Rudolph 2007; Wyatt 2017; Zarhani 2019). The abolition of industrial licensing and the transformation of the centrally planned economy paved the path for the birth of a 'federal market economy' with the significant role of regional political leaders. Sub-national state governments now enjoyed substantially greater powers over investment regulation than the central government in their jurisdictions. Consequently, investment friendly states such as Tamil Nadu could even compete with China or Malaysia for investments, whereas backward ones such as Bihar or Uttar Pradesh resembled sub-Saharan Africa (Mukherji and Singh 2006).

Furthermore, the mounting debts of the sub-national states convinced Prime Minister Vajpayee's NDA government (1998-2004) to make the states more responsible for their finances. Prime Minister Vajpayee initiated the Fiscal Responsibility and Budget Management Act (FRBM Act) in 2003, which was adopted by the sub-national states as well. The FRBM restricted the amount that the states could borrow up to a limit of $3.0 \%$ of GSDP. Moreover, in 2005, the central government stopped the central plan loans (the Normal Central Assistance loans). Instead, it offered debt swap schemes, in which the states could refinance their expensive loans with lower interest rates (For more details, see Karnik 2002; Pattnaik 2016). These policy shifts enjoyed bipartisan support and were pursued by the United Progressive Alliance (UPA) government after 2004 (till 2014) as well. In the early years of the UPA government (2005-6), the flow of loans from the central government stopped almost entirely. The result was fiscally reassuring: as we can see in Fig. 1, the subnational states' total outstanding liabilities reached the historical record low of $21 \%$ $(2014 / 15) .^{25}$

The current imbroglio regarding the GST compensation signals the beginnings of a drift towards centralization of decision-making and financial allocations to the sub-national states. How did the reversal of the above-mentioned federal trajectory

\footnotetext{
${ }^{24}$ The Constitution of India in the State List or List-II gave lots of taxation powers to the states such as on sale of goods, excise duty on alcohol, transportation taxes, tax on agriculture incomes, octroi, stamp duties on sale of land and other properties and a few other taxes.

${ }^{25}$ For the positive impact of the fiscal reforms on the sub-national state finances see Badaik (2017).
} 


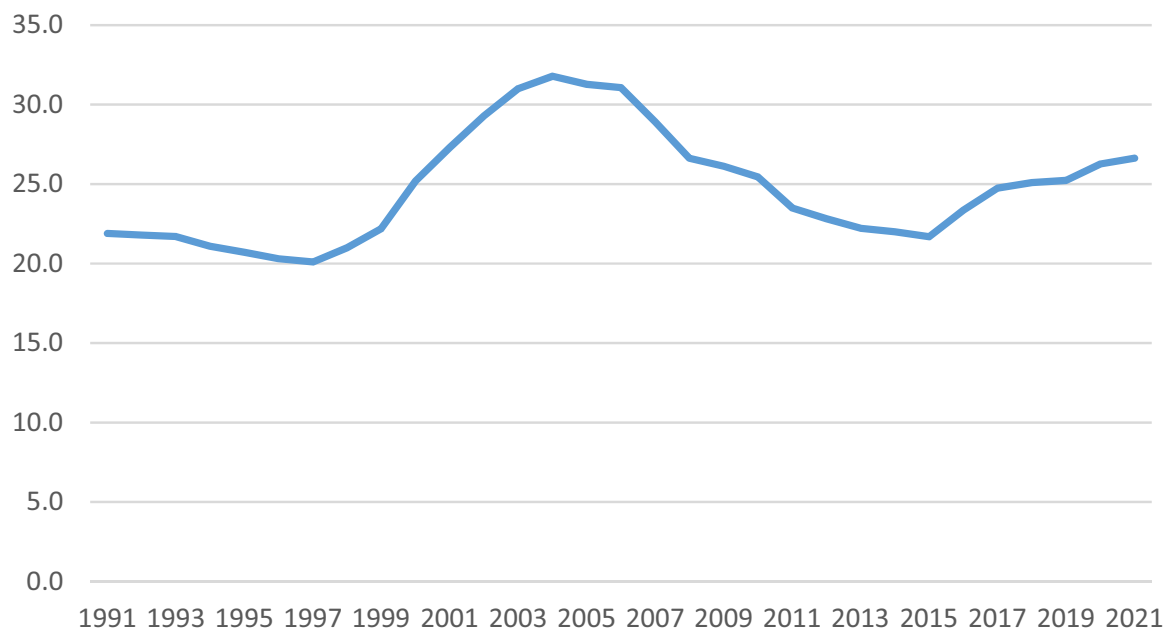

Fig. 1 Total outstanding liabilities - as percentage of GSD, drawn by the authors, source of data: Reserve Bank of India (2012, 2020b)

occur after 2014? The GST transformed the fiscal relationship between the subnational states and the Centre in 2017. The new Goods and Services Tax (GST) was implemented to rationalize India's indirect tax regime. The GOI replaced the previous structure of separate taxation authority for the Centre and the sub-national states with a shared taxation system for the bulk of the indirect taxes. The Centre and states had collaborated to produce a GST framework with certain veto powers that rest with the Centre (Aiyar and Tillin 2020). Its evolution was a layered process of incremental change under different governments with varied professed ideologies. ${ }^{26}$ Prime Minister Modi of the NDA succeeded where Prime Minister Manmohan Singh of the UPA (2004-2014) had failed.

The GST negotiations had accorded due respect to the sub-national states. The sub-national state governments' main concern regarding the GST was the risk of a severe reduction in their revenues. To address this issue, the Parliament enacted the GST (Compensation to States) in 2017 with the guarantee that all sub-national states will receive compensation at an annual growth rate of $14 \%$ in their GST revenue over the base year 2015-16 for a period of 5 years. This guarantee had satisfied the sub-national states.

COVID-19 opened up a new opportunity for the central government to drift towards centralization of the union government's financial powers with respect to the states. The old legal framework was deployed by the Centre to unilaterally thrust its view on the sub-national states. The slowdown of economic growth rate in the 3 years from 2017 to 2010 coupled with the consequences of the COVID-19

${ }^{26}$ For history of tax reforms before the GST see Acharya (2005) and Nayar (2011). 
pandemic such as lockdowns and mass unemployment ${ }^{27}$ had negatively impacted GST collections. The NDA government justified reneging its revenue sharing promise by invoking the COVID-19 pandemic as an "act of God" (Menon 2020). This mechanism would especially hurt fiscally constrained states. The financial pain was more acute for the sub-national states during the pandemic, because health was a sub-national state subject.

The central government departed from convention and directed a compensation plan without consulting the states. According to this design, the calculation of GST shortfall, Rupees (Rs.) 97,000 crores ( $\$ 13.25$ billion) will be a borrowing of the central government through a special window of the Reserve Bank of India. This would enter into the loan account of the sub-national state governments. The Centre would compensate the states for this borrowing through the taxes collected by it in the future. To add to this, the COVID-19 expenditures are estimated at Rs. 1.38 lakh crores ( $\$ 18.86$ billion). This shortfall can be met in two ways. First, states can borrow up to $5 \%$ of their GSDP from the market. The central government will pay the principal amount, but the states will have to pay the interest on the principal. Moreover, any borrowing greater than $3.5 \%$ of the GSDP will come with conditions from the union government. Alternatively, the states can borrow up Rs. 1.38 lakh crores under similar conditions (Gupta and Rajaraman 2020). This is considered to be the COVID-19 shortfall, which is being touted as "the act of God". ${ }^{28}$

There are two reasons to code this episode as an endogenous drift in the path rather than an exogenously induced critical juncture. First, at the $41^{\text {st }}$ meeting of the GST Council (August 27 2020), Punjab's Finance Minister objected to the Accountant General's claim that the Centre had no commitment to pay. This, he argued, was a different claim from one that would suggest that paucity of funds was the reason for reneging on commitments. Other finance ministers also affirmed that the government had given a firm revenue commitment in the GST Act. Second, Kerala's Finance Minister reminded the Council that the Centre had begun socializing the sub-national states with the view that the revenue pledge made by the Centre in 2017 would not be respected as long back as 22 December 2018 at the 31st GST Council meeting in Goa. We code this non-compliance of the promised revenue share commitment as an endogenous drift, because the Centre had begun to push for centralization much before COVID-19 arrived on the scene. ${ }^{29}$ The exogenous COVID19 shock, according to this view, is less important than endogenous norm evolution towards financial centralization within the Central Government.

The GST compensation and COVID-19 shortfall were an imposition on the subnational state governments without taking their views into consideration. Consequently, there have been heated exchanges in the GST Council with a large number of states. States such as Kerala had invested \$2.6 billion to ensure that migrant

\footnotetext{
27 For example, the Centre for Monitoring the Indian Economy reported that India's unemployment rate in April 2020 (After the COVID-19 lockdown) was at a record high of 27.1\% (Inamdar, 2020).

28 These views are also based on discussions with Subhash Chandra Garg a retired civil servant who was Finance Secretary in the Ministry of Finance (telephonic interview, New Delhi, January 14, 2021).

${ }^{29}$ For the details see Minutes of the 41st GST Council Meeting (Goods \& Services Tax Council, 2020).
} 
labour and residents were cared for, and to ensure effective contact tracing and quarantine. For being successfully proactive, the sub-national state was compensated to the tune of a paltry \$200 million (Mukherji 2020, 95-96).

This section describes how the central government is drifting towards unionization from a situation where the FRBM had rendered the states more responsible for their finances. That arrangement had reduced the deficit of the sub-national states. GST with the promise of compensation was negotiated with the sub-national states. The norm of federally consulted revenue allocations is drifting towards centralization of financial allocations, because the Centre is trying to reverse the federalising imperative that had endured till 2014/15. Centralization of fiscal authority has arisen in the context of prevailing rules by just interpreting them differently.

\section{Conclusion}

The two Indian cases demonstrate that paths and ideas need to be considered simultaneously for understanding the causal mechanism behind change in economic institutions. The PPLTDM highlights the importance of ideas in layered progression towards deregulation from a situation of stringent industrial controls in the 1980s. Layering, or gradual overt change in policy settings and instruments was necessitated by powerful veto groups and clearly stated policies that could not be interpreted ambiguously. This layered progression involved a change in policy settings such as investment and import deregulation. It also led to the creation of new policy instruments such as the modified value added tax, the CDOT, the DOT, the MTNL and the software technology parks. Taken together these changes in policy settings and instruments took India a long distance towards the deregulation and competitiveness paradigm. The system tipped in 1991 when the Indian state could deploy a balance of payments crisis to deal with powerful veto players opposed to deregulation and competitiveness. India's approach to 1991 was to change the policy paradigm towards deregulation and globalization. In 1966, on the other hand, when India was equally vulnerable and IS was the hegemonic paradigm, the country made minimal short-term adjustments like devaluation to revert back to the status quo of industrial controls. The period between 1969 and 1974 was perhaps the most highly regulated in India's economic history.

Historical institutionalism is more adept at understanding gradual processes such as drift, layering and conversion than more sudden phenomena such as displacement. Combining the principles of gradual evolution in a layered change in institutions and policies, with a path that tips, can throw light on why displacement may be caused by gradual processes. Moreover, what looks sudden is the result of a sustained, gradual and endogenous change rather than the result of an exogenous shock.

Our second case throws light on policy paradigms and drift. When ambiguous rules allowed, and veto powers were powerful, the central government could gradually nudge the fiscal paradigm from federal responsibility towards central direction without any explicit change in policies and rules. The GST compensation and COVID-19 expenditures had put a severe strain on the budgets of sub-national states. Normally, decisions would require consultations with the sub-national states. 
The manner in which the Centre imposed its will on the sub-national states during the COVID crisis, signals a drift inspired by a centralizing fiscal paradigm that has taken hold of the Central government.

The gradual evolution of policy paradigms through mechanisms such as drift and layering are especially relevant in a world where democratic backsliding and ethnic nationalism seem to surprise all those who have a conventional view of modernity. It may be important to trace gradual endogenous change in policy paradigms to understand when they may surprisingly tip to displace the conventional liberal democratic paradigm—so that norms such as democracy and secularism remain secure.

Acknowledgements We thank Yijia Jing for inviting us to write this paper. The authors thank Mark Blyth, Jack Snyder, Jagdish Bhagwati, David Baldwin, Montek Singh Ahluwalia, Subhash Chandra Garg, (late) Michael Liebig, Partha Nath Mukherji and Atul Sarma for their insights. We thank Ronja Gottschling and Tanvi Deshpande for reading and editing the paper. The paper has benefited from presentations at Columbia University (New York), Fudan University (Shanghai), Heidelberg University (Heidelberg), University of Sheffield (Sheffield), Jawaharlal Nehru University (New Delhi) and Jamia Milia Islamia (New Delhi).

Funding The research was funded by the Department of Political Science, South Asia Institute, Heidelberg University. The authors also benefited from a European Union Horizon 2020 grant-No. 722446.

\section{Compliance with ethical standards}

Conflict of interest The authors claim there is no conflict of interest in terms of the publication of this paper.

\section{References}

Acemoglu, D., \& Robinson, J. A. (2012). Why nations fail: The origins of power, prosperity and poverty. London: Profile.

Acharya, S. (2005). Thirty years of tax reform in India. Economic and Political Weekly, 40(20), 2061-2070.

Ahluwalia, M. S. (2020). Backstage: The story behind India's high growth years. New Delhi: Rupa Publications.

Aiyar, Y., \& Tillin, L. (2020). “One Nation,” BJP, and the future of Indian federalism. India Review, 19(2), 117-135.

Alexander, P. C. (1978). Report of the committee on import-export policies and procedures. New Delhi: Ministry of Commerce.

Athreya, M. B. (1996). India's telecommunications policy: A paradigm shift. Telecommunications Policy, 20(1), 11-22.

Badaik, S. (2017). Impact of fiscal responsibility legislations on state finances in India. Theoretical \& Applied Economics, 24(3), 115-124.

Bardhan, P. (1984). The political economy of development in India. Oxford: Basil Blackwell.

Béland, D. (2007). Ideas and institutional change in social security: Conversion, layering, and policy drift. Social Science Quarterly, 88(1), 20-38.

Bhagwati, J., \& Desai, P. (1970). India: Planning for industrialization. London: Oxford University Press.

Bhagwati, J., \& Srinivasan, T. N. (1975). Foreign trade regimes and economic development: India (for the National Bureau of Economic Research). New York: Columbia University Press.

Bhagwati, J., \& Srinivasan, T. N. (1980). Revenue seeking: A generalization of the theory of tariffs. Journal of Political Economy, 88(6), 1069-1087.

Blyth, M. (2002). Great transformations: Economic ideas and institutional change in the twentieth century. Cambridge: Cambridge University Press. 
Blyth, M. (2013). Policy paradigms in two moments of crisis. Governance, 26, 197-215.

Blyth, M., Helgadottir, O., \& Kring, W. (2016). Ideas and historical institutionalism. In O. Fioretos, T. Falleti, \& A. Sheingate (Eds.), The Oxford handbook of historical institutionalism (pp. 143-163). Oxford: Oxford University Press.

Boughton, J. M. (2003). Who's in Charge? Ownership and conditionality in IMF supported programs, IMF working paper 03/191 (September). Washington: International Monetary Fund.

Capoccia, G., \& Kelemen, R. D. (2007). The Study of critical junctures: Theory, narrative, and counterfactuals in historical institutionalism. World Politics, 59(3), 341-369.

Capoccia, G. (2016). Critical junctures. In O. Fioretos, T. Falleti, \& A. Sheingate (Eds.), The Oxford handbook of historical institutionalism (pp. 89-106). Oxford: Oxford University Press.

Carstensen, M. B., \& Matthijs, M. (2018). Of paradigms and power: British economic policy making since Thatcher. Governance, 31(3), 431-447.

Chaudhry, P. K., Kelkar, V. L., \& Yadav, V. (2004). The evolution of 'homegrown conditionality' in India: IMF relations. Journal of Development Studies, 40(6), 59-81.

Dagli, V. (1979). Report of the committee on controls and subsidies. New Delhi: Ministry of Finance.

Daigneault, P.-M. (2014). Reassessing the concept of policy paradigm: Aligning ontology and methodology in policy studies. Journal of European Public Policy, 21(3), 453-469.

David, P. A. (1985). Clio and the economics of QWERTY. The American Economic Review, 75(2), 332-337.

Denoon, D. B. H. (1986). Devaluation under pressure: India, Indonesia, and Ghana (Vol. 1). Cambridge: The MIT Press.

Derthick, M., \& Quirk, P. J. (1985). The politics of deregulation. Washington, DC: Brookings Institution.

Desai, A. (2003). India's telecommunications industry: History, analysis and diagnosis. New Delhi: Sage Publication.

Ganguly, S., \& Mukherji, R. (2011). India since 1980. New York: Cambridge University Press.

Garg, S. C. (2021, forthcoming). Oscillating between fiscal federalism and unionism: Evolution, operation and reforms in fiscal relations between the Centre and the States in India. In R. Mukherji, J. Prasad, H. Jha, \& S. H. Zarhani (Eds.), Governing India. New Delhi: Routledge.

Goods \& Services Tax Council. (2020). Minutes of the 41st GST Council Meeting held on 27th August 2020. http://www.gstcouncil.gov.in/sites/default/files/Minutes/Minutes-\%2041st\%20GSTC\%20Mee ting.pdf. Accessed 25 Jan 2021.

Gupta, M., \& Rajaraman, I. (2020). Is the $14 \%$ revenue guarantee to states justified? Economic and Political Weekly, 55(47), 18-21.

Hacker, J. S. (2004). Privatizing risk without privatizing the welfare state: The hidden politics of social policy retrenchment in the United States. The American Political Science Review, 98(2), 243-260.

Hacker, J. S., Pierson, P., \& Thelen, K. (2015). Drift and conversion: Hidden faces of institutional change. In J. Mahoney, \& K. Thelen (Eds.), Advances in comparative-historical analysis (pp. 180-208, strategies for social inquiry). Cambridge: Cambridge University Press.

Hall, P. A. (1993). Policy paradigms, social learning, and the state: The case of economic policymaking in Britain. Comparative Politics, 25(3), 275-296.

Hirschman, A. O. (1989). How the Keynesian revolution was exported from the United States, and other comments. In P. A. Hall (Ed.), The political power of economic ideas: Keynesianism across nations. Princeton: Princeton University Press.

Hussain, A. (1984). Report of the committee on trade policy. New Delhi: Ministry of Commerce.

Inamdar, N. (2020). Coronavirus lockdown: India jobless numbers cross 120 million in April. BBC News. https://www.bbc.com/news/world-asia-india-52559324. Acessed 16 Dec 2020.

Jenkins, R. (1999). Democratic politics and economic reform in India. Cambridge: Cambridge University Press.

Jha, H. (2020). Capturing institutional change: The case of the right to information act in India. New Delhi: Oxford University Press.

Joshi, V., \& Little, I. M. D. (1994). India: Macroeconomics and political economy. New Delhi: Oxford University Press.

Kantha, S., \& Ray, S. (2006). Building India with partnership: The story of CII 1895-2005. New Delhi: Penguin Books.

Karnik, A. (2002). Fiscal responsibility and budget management bill: Offering credible commitments. Economic and Political Weekly, 37(3), 251-256.

Kochanek, S. A. (2007). Liberalization and business lobbying in India. In R. Mukherji (Ed.), India's economic transition. New Delhi: Oxford University Press. 
Kohli, A. (2006). Politics of economic growth in India, 1980-2005. Economic and Political Weekly, 41(14), 1361-1370.

Koreh, M., Mandelkern, R., \& Shpaizman, I. (2019). A dynamic theoretical framework of gradual institutional changes. Public Administration, 97(3), 605-620.

Krasner, S. (1984). Approaches to the state: Alternative conceptions and historical dynamics. Comparative Politics, 16(2), 223-246.

Krueger, A. O. (1974). The political economy of the rent-seeking society. The American Economic Review, 64(3), 291-303.

Mahoney, J., \& Thelen, K. (2010). A theory of gradual institutional change. In J. Mahoney \& K. Thelen (Eds.), Explaining institutional change: Ambiguity, agency, and power (pp. 1-37). Cambridge: Cambridge University Press.

Menahem, G. (2008). The transformation of higher education in Israel since the 1990s: The role of ideas and policy paradigms. Governance, 21(4), 499-526.

Menon, R. (2020). Acts of god and the all-important GST pact between the state and centre. The Wire. https://thewire.in/economy/acts-of-god-and-the-all-important-gst-pact-between-the-state-and-centr e. Acessed 16 Dec 2020.

Mukherji, R. (2007). Economic transition in a plural polity: India. In R. Mukherji (Ed.), India's economic transition: The politics of reforms. New Delhi: Oxford University Press.

Mukherji, R. (2009). Interests, wireless technology, and institutional change: From government monopoly to regulated competition in Indian telecommunications. The Journal of Asian Studies, 68(2), 491-517.

Mukherji, R. (2013). Ideas, interests, and the tipping point: Economic change in India. Review of International Political Economy, 20(2), 363-389.

Mukherji, R. (2014). Globalization and deregulation: Ideas, interests, and institutional change in India. New Delhi: Oxford University Press.

Mukherji, R. (2020). Covid vs. democracy: India's illiberal remedy. Journal of Democracy, 31(4), 91-105.

Mukherji, R., \& Singh, A. (2006). Investing. In The Indian special economic zones a background paper. ISAS working papers, 12. Singapore: Institute of South Asian Studies.

Mukherji, R., Jha, H., \& Roy, M. (2019). Ideas and policy paradigms: Explaining the fall of welfare politics in West Bengal. Indian Politics \& Policy Journal, 2(2), 53-80.

Narasimhan, M. (1985). Committee to examine the principles of a possible shift from financial to physical controls-final report. New Delhi: Ministry of Finance.

Nayar, B. R. (2006). When did the "Hindu" rate of growth end? Economic and Political Weekly, 41(19), 1885-1890.

Nayar, B. R. (2011). Globalization, the state, and India's halting march to common market: The political economy of tax reform under federalism. India Review, 10(3), 201-245.

North, D. C., \& Weingast, B. R. (1989). Constitutions and commitment: The evolution of institutions governing public choice in seventeenth-century England. The Journal of Economic History, 49(4), 803-832.

Panagariya, A. (2008). India: The emerging giant. Oxford: Oxford University Press.

Patel, I. G. (1987). On taking India into the twenty-first century (new economic policy in India). Modern Asian Studies, 21(2), 209-231.

Patel, I. G. (2003). Glimpses of Indian economic policy: An insider's view. New Delhi: Oxford University Press.

Patnaik, P., \& Chandrasekhar, C. (2007). Indian economy under "Structural Adjustment." In R. Mukherji (Ed.), India's economic transition (pp. 301-313). New Delhi: Oxford University Press.

Pattnaik, R. K. (2016). Fiscal responsibility and budget management act: An Indian perspective. In C. Singh (Ed.), Public debt management: Separation of debt from monetary management in India (pp. 105-130). New Delhi: Springer India.

Pedersen, J. D. (2000). Explaining economic liberalization in India: State and society perspectives. World Development, 28(2), 265-282.

Pierson, P. (2004). Politics in time: History, institutions, and social analysis. Princeton: Princeton University Press.

Pingle, V. (1999). Rethinking the developmental state: India's industry in comparative perspective. New Delhi: Macmillan.

Posner, R. A. (1974). Theories of economic regulation. The Bell Journal of Economics and Management Science, 5(2), 335-358. 
Reserve Bank of India. (2012). State finances: A study of budgets of 2011-12. https://rbidocs.rbi.org.in/ rdocs/Publications/PDFs/STF30032012.pdf . Acessed 16 Dec 2020.

Reserve Bank of India. (2020a). State finances: A study of budgets of 2020-21. https://www.rbi.org.in/ Scripts/AnnualPublications.aspx ?head=State $\% 20$ Finances $\% 20: \% 20$ A $\% 20$ Study $\% 20$ of $\% 20$ Budgets. Acessed 16 Dec 2020.

Reserve Bank of India. (2020b). Annual report of the RBI for the year 2019-20. https://rbidocs.rbi.org. in/rdocs/AnnualReport/PDFs/0RBIAR201920DA64F97C6E7B48848E6DEA06D531BADF.PDF. Acessed 17 Dec 2020.

Rodrik, D., \& Subramanian, A. (2004). From "Hindu Growth" to productivity surge: The mystery of Indian growth transition (The IMF Working Paper 04.77). Washington DC: International Monetary Fund.

Rodrik, D., \& Subramanian, A. (2005). From "Hindu Growth" to productivity surge: The mystery of the Indian growth transition. IMF Staff Papers, 52(2), 193-228.

Rubin, B. R. (1985). Economic liberalisation and the Indian State. Third World Quarterly, 7(4), 942-957.

Rudolph, L., \& Rudolph, S. H. (2007). The iconization of Chandrababu: Sharing sovereignty in India's Federal Market Economy. In R. Mukherji (Ed.), India's economic transition: The politics of reforms (pp. 231-264). New Delhi: Oxford University Press.

Ruggie, J. G. (1983). International regimes, transactions, and change: Embedded liberalism in the postwar economic order. In S. D. Krasner (Ed.), International regimes. Ithaca: Cornell University Press.

Saez, L. (2002). Federalism without a centre: The impact of political and economic reform on India's federal system. New Delhi: Sage Publications.

Saxenian, A. (2007). Bangalore: The silicon valley of Asia? In R. Mukherji (Ed.), India's economic transition: The politics of reforms (pp. 359-387). New Delhi: Oxford University Press.

Sharma, D. C. (2009). The long revolution: The Birth and growth of India's IT industry. New Delhi: Harper Collins.

Shetty, M. (2020). States' debt to hit $36 \%$ of their GDP. Times of India. https://timesofindia.indiatimes .com/business/india-business/states-debt-to-hit-36-of-their-gdp/articleshow/79518584.cms. Accessed 5 Jan 2021.

Sinha, A. (2005). Understanding the rise and transformation of business collective action in India. Business and Politics, 7(2), 1-35.

Singh, P. (2020). BJP's farming policies deepening agrobusiness capitalism and centralisation. Economic and Political Weekly., 55(41), 14-17.

Sridharan, E. (2008). The political economy of the middle classes in liberalising India. ISAS working papers, 49. Singapore: Institute of South Asian Studies.

Sridharan, K. (1996). The ASEAN region in India's foreign policy. Aldershot: Dartmouth Publishing Company.

Stigler, G. (1971). The theory of economic regulation. The Bell Journal of Economics and Management Science, 2(1), 3-21.

Stone, R. W. (2008). The scope of IMF conditionality. International Organization, 62(4), 589-620.

Streeck, W. (2014). Buying time: The delayed crisis of democratic capitalism. Verso Books.

Streeck, W., \& Thelen, K. A. (2005). Introduction: Institutional change in advanced political economies. In W. Streeck \& K. A. Thelen (Eds.), Beyond continuity: Institutional change in advanced political economies (pp. 1-39). Oxford: Oxford University Press.

Subramanian, A. (2019). India's GDP mis-estimation: Likelihood, magnitudes, mechanisms, and implications. cid working paper series, 2019.354. Cambridge: Harvard University.

Tsai, K. S. (2006). Adaptive informal institutions and endogenous Institutional change in China. World Politics, 59(1), 116-141.

Vreeland, J. R. (2003). The IMF and economic development. Cambridge: Cambridge University Press.

Wyatt, A. (2017). Paradiplomacy of India's chief ministers. India Review, 16(1), 106-124.

Zarhani, S. H. (2019). Governance and development in India: A comparative study on Andhra Pradesh and Bihar after liberalization. London: Routledge. 